\title{
PRÁTICAS DE CONTROLE SOCIAL NA ERA DO PÓS-PANOPTISMO: ANÁLISE DO BANCO DE DADOS GENÉTICOS
}

\author{
Caroline Viera* \\ Celso Rodrigues**
}

\begin{abstract}
RESUMO
O presente artigo busca avaliar a introdução do banco de dados de perfil genético aos condenados por crimes violentos contra a pessoa, analisando a previsão legal e as agências oficiais de punitividade edificadas para a sua aplicação. A pesquisa realiza uma reflexão sobre os dados oficiais disponibilizados pela Rede Integrada de Bancos de Dados Genéticos, buscando demonstrar um câmbio gradual das práticas de controle penal. A reflexão relaciona-se com a superação do modelo de vigilância panóptica descrita por Michel Foucault e reproblematizada por Zygmunt Bauman, elaborada enquanto consequência da volatilidade das relações sociais, que caracterizam-se por um processo constante de inacessibilidade e recusa ao engajamento entre vigias e vigiados. Destacam-se nesse estudo as conclusões derivadas do paradigma da reação social diante da reificação da seletividade incorporada a esta prática de controle, com referencial teórico em Jock Young e Vera Andrade.
\end{abstract}

PALAVRAS-CHAVE: Banco de dados genéticos; Controle social; Pós-pa noptismo; Seletividade.

* Advogada. Mestre em Ciências Criminais pela PUCRS, Professora de Direito Penal e Processo Penal do Centro Universitário Metodista IPA. Email: caroline. viera@metodistadosul.edu.br

** Sociólogo, historiador. Doutor em História pela PUCRS. Coordenador do Projeto Direitos Humanos na Prisão. Professor da Especialização em Ciências Penais da PUC/RS, e de Sociologia Jurídica da Faculdade de Direito do Centro Universitário Metodista IPA. E-mail: santograal63@hotmail.com 


\begin{abstract}
This article seeks to evaluate the introduction of the genetic profile database to convicted of violent crimes against the person, analyzing legal provisions and official agencies punitividade built for your application. Research conducts a reflection on the official data provided by the Integrated Network of Genetic Databases, seeking to demonstrate a gradual exchange of criminal control practices. Reflection relates to overcoming the panoptic surveillance model described by Zygmunt Bauman, prepared as a result of the volatility of social relations, which are characterized by a constant process of inaccessibility and refusal to engage between guards and monitored. Stand out in this study the conclusions derived from the social reaction paradigm before the reification of selectivity incorporated the practice of control, with theoretical framework in Jock Young and Vera Andrade.
\end{abstract}

KEYWORDS: Genetic data base; Social control, Post panoptism; Criminal selectivity.

\title{
1. INTRODUÇÃO
}

A construção de uma sociedade democrática sob a inspiração de uma ordem constitucional é um processo que se desenvolve na duração histórica, e no espaço social, locus privilegiado, onde travam-se as batalhas entre forças de transformação e forças de conservação, na célebre definição de Polanyi (POLANYI, 2000).

A história da redemocratização brasileira deve ser compreendida à luz dessa processualidade sócio-histórica, e a ordem jurídica inscreve-se no interior dessa dinâmica. Nestes termos, falar em modernidade jurídica implica perceber essa "luta pelo Direito" que não contempla um termo final, mas uma lógica conflitual, conforme lembra Weber (WEBER, 2001). Neste cenário, o Direito torna-se um instrumento que transcende sua lógica meramente ordenadora, para fornecer uma produção de sentido que torna-se fundamental nas sociedades modernas ocidentais. A lógica eruptiva da onde emergem os processos de juridificação dizem respeito às tensões e lutas presentes na sociedade, indicando a intensidade da democracia na definição de Santos 
(SANTOS, 2002).

A inserção abrupta do Brasil nos fluxos da globalização capitalista a partir da década de 90 acrescentou ao quadro anteriormente descrito um grau de complexidade mais amplo. Evidentemente as transformações estruturais experenciadas na sociedade brasileira se articularam dialogicamente às mudanças na ordem jurídica que forneceu instrumentos ou sofreu supressões. Como lembrou Sorj (SORJ, 2000) nas últimas décadas, imensos contingentes da sociedade brasileira viveram a experiência de "perda de direitos". Por outro lado, uma copiosa produção legislativa foi erguida, principalmente voltada para enfrentar os desequilíbrios sociais originados da emergência abrupta e violenta de uma nova lógica societária, ancorada na precarização das relações sociais. Diversos autores já se debruçaram na investigação acerca das novas formas de controle, resumidas no precário conceito de Estado Penal. Nos limites desse artigo nos propomos a debater esta questão a partir de um objeto específico: a criação do banco de dados genético no Brasil. Esta iniciativa inscreve o Estado brasileiro no conjunto dos governos interessados em erigir controles sociais inspirados numa espécie de pós-panoptismo de legitimidade contestável, como veremos.

Historicamente o Jusnaturalismo moderno constituiu-se como arcabouço ideológico da autonomia do indivíduo diante do Estado. Naquele contexto histórico trata-se de reconstruir os pilares de legitimidade da autoridade estatal, tendo como ponto de partida não mais a soberania plenipotenciária do Estado Absolutista, mas o indivíduo moderno, racional, e dotado de direitos. É nesse contexto de modificação que é necessário pensar o constitucionalismo contemporâneo, com prioridade no constitucionalismo brasileiro, por isso passaremos a refletir sobre o banco de dados genéticos no processo penal brasileiro.

No seio de um processo redemocratizador, o ser humano é revalorizado e o processo penal assume significado e finalidade 
política e jurídica, de garantir que o homem não seja sacrificado por razões de utilidade, no dizer de BETTIOL (BETTIOL, 1976, p.174). Por isso, a Constituição Federal, em seu artigo 5o, incisos LVII e LVIII, garantindo a presunção de inocência, ressalvou o direito fundamental de não auto-incriminação, expresso no brocardo nemo tenetur se detegere (nada a temer por se deter), o que implica, dentre um de seus efeitos, o direito ao silêncio, sem que a negativa de produzir prova possa ser interpretada em prejuízo do réu.

O direito ao silêncio - nemo tenetur se detegere, ou ainda, como sustenta Claus Roxin (ROXIN, pp. 121-158) nemo tenetur se ipsum accusare (ninguém deve acusar a si mesmo), está inserido no artigo 5ํㅜ inciso LXIII da Constituição Federal que determina: o preso será informado de seus direitos, entre os quais o de permanecer calado, sendo-lhe assegurada a assistência da família e de advogado e decorre também da inclusão, no ordenamento jurídico brasileiro do artigo 8o, 2, 'g', do Decreto 678/92, o Pacto de São José da Costa Rica.

0 direito de silêncio, assim, é entendido como uma opção política, no sentido de um processo penal democrático, cuja função primordial é a contenção do poder punitivo. Neste viés, repudiam-se as práticas autoritárias e afasta-se a pretensão pela busca de uma verdade, seja ela real ou processual, pensando com CARNELUTTI, apoiado em HEIDEGGER (CARNELUTTI, 1965, P. 4-9), admitindose apenas a possibilidade contingencial de atingí-la, sem que seja fundante do processo (LOPES JUNIOR, 2012, pp. 575).

A presunção de inocência e o direito de não se auto-incriminar são um manto protetor dos inocentes, compreendidos como o elo mais fraco do processo, servindo a lei como "o limite ao poder desmesurado - leia-se, limite à dominação. Então, a lei - eticamente considerada - é proteção ao débil“ (BUENO DE CARVALHO, 2001, p. 56 e ss.). 0 processo penal torna-se, então, um instrumento a serviço da realização do projeto democrático, 
ainda que para isso tenha-se que pagar o preço da impunidade de algum culpável o que, segundo Jacinto Coutinho "é um preço a ser pago pela democracia (não avançar nos direitos e garantias individuais)" (COUTINHO, 2001, p. 177).

Por estas razões a identificação criminal apenas é admitida constitucionalmente em hipóteses excepcionais, as quais foram dispostas na Lei 12.037/2009. Essencialmente esse diploma prevê a possibilidade de identificação criminal em casos de insuficiência de documentos de identificação, de indícios de falsificação de documento, de documentos com identificação conflitante, ou ainda em casos de necessidade para as investigações, por representação da autoridade policial, autorizado mediante despacho judicial fundamentado (artigo 3o da Lei 12037/2009).

Na hipótese de necessidade para as investigações, a identificação criminal, além de excepcional e dependente de decisão judicial, apenas justificar-se-ia como meio de prova para eventual processo, podendo ser excluída mediante requerimento do indiciado ou do réu, em caso de não oferecimento da denúncia, ou sua rejeição, ou absolvição, após o arquivamento definitivo do inquérito, ou trânsito em julgado da sentença, bastando para isso, que apresente o investigado as provas de sua identificação civil (art. 7ํㅡㅁ Da Lei 12.037/2009).

A identificação era realizada apenas mediante processo datiloscópico e o fotográfico, até que a Lei 12.654/2012 inseriu a possibilidade de extração de material biológico (art. 5ำ § único Lei 12037/2009) para a alimentação de um banco de dados de perfil genético, sendo que a intervenção corporal deverá ser realizada sem o constrangimento do identificado (art. 7ํ da Lei 12037/2009), durante o curso da investigação que precede o ajuizamento da ação penal.

O exame de DNA pode ser considerado como uma evolução na disciplina das provas, sobretudo no processo penal, onde em geral a prova produzida concentra-se eminentemente na prova 
oral, com oitiva de vítimas, testemunhas e interrogatórios dos acusados. A prova técnica nesse sentido pode contribuir com a elucidação de fatos, sobretudo em casos complexos que envolvam violência física, sexual e homicídios. Não obstante os aspectos modernizadores envolvidos, sempre é importante lembrar a persistência das tradições jurídicas e policiais na sociedade brasileira que dão conta de uma dinâmica prisional perversa onde a palavra da polícia tem grande relevância.

\footnotetext{
Diversas pesquisas retratam a dinâmica dessas prisões: a maioria dos flagrantes é realizada em vias públicas, por patrulhamento ou denúncia, com pouca investigação posterior. $\mathrm{Na}$ fase judicial, o Ministério Público agrava a acusação, com provas escassas, sendo o testemunho do policial envolvido o principal elemento de acusação. A fim de prestigiar o trabalho das polícias, esses testemunhos embasam a manutenção da prisão provisória e posterior condenação dos acusados. Uma série de questões deve ser feita sobre esse procedimento pouco justo. (LOBO, 2015).
}

Essa advertência é necessária, na medida em que a reflexão crítica impõe a necessidade de pensar o conceito de modernização de forma a não excluir as relações apoiadas na tradição, neste caso em especial, a condição de "fé pública" assumida pela palavra da polícia. Além disso, não devemos perder de vista a enraizada tradição inquisitorial que estrutura o processo penal brasileiro, reificando tradições em torno de discursos de autoridade. Lembremos que esta referida tradição histórica construiu uma leitura do "capital simbólico" do direito (BOURDIEU, 1989) enquanto expressão da sabedoria de elites ilustradas, ou seja, das "autoridades" que, ao contrário da vontade geral rousseaunina, são os verdadeiros detentores da verdade no Direito. Colocado em andamento o aparato jurídico-criminal vai brandir a espada inquisitorial que reitera a hierarquia social sob o signo da condenação.

Dessa forma, a modernização esperada em termos de eficácia e de novos procedimentos não diz respeito a uma transformação dos quadros de referência ideológicos que norteiam o 
campo jurídico-criminal. Assim sendo, envolvem essencialmente a mobilização de amplos recursos financeiros, investimentos em treinamento de pessoal especializado, tecnologias e recursos de pesquisa para a perícia forense, em busca de uma eficácia imaginada num modelo fordista. Mas, como já foi assinalado, tais processos não ocorrem num vazio social capaz de engendrar a suspensão de valores sociais e seu campo de significações.

Como sabemos, o emprego de novas técnicas nascidas do desenvolvimento científico não ocorre num espaço de neutralidade, mas condicionado à experiência social. Ainda que a evolução dos métodos de obtenção da prova seja bem vinda, não se pode desconsiderar no horizonte desse processo os riscos de sobreposição que a busca de solução dos casos penais podem implicar em relação aos direitos e garantias fundamentais dos acusados, em especial, nessas circunstâncias, ao direito de silêncio, ou de não auto-incriminação.

Não por outro motivo a extração de material genético só poderia ocorrer caso respeitasse a dignidade dos investigados, sendo dependente de sua anuência no fornecimento de tecidos, sangue, saliva ou cabelo, e nunca de forma compulsória. Caso não exista concordância por parte do réu para a extração de qualquer material (saliva, cabelo, etc.), unicamente poderá ser recolhido aquele encontrado na cena de crime, ou junto à vítima, ou à testemunha. Diante daquele que detém o "monopólio do exercício da violência legal" na célebre definição de Weber, as relações estabelecidas caracterizam-se pela desigualdade. 0 direito de não produzir prova contra si representa, portanto um bastião de proteção aquele que é a priori, inocente.

Ocorre que a mesma lei que permitiu a extração de material genético mediante deferimento judicial (em relação aos investigados e ou processados por suposto delito), também incluiu na Lei de Execuções Penais, o artigo 9-A, obrigando que todo o condenado por crime doloso, com violência de natureza grave à 
pessoa, ou por qualquer dos crimes previstos no artigo $1^{0} \mathrm{da}$ Lei 8072/90, seja submetido à identificação de perfil genético, mediante extração de DNA.

A norma evidencia a tendência de uma expansão criminalizadora do controle penal, nos termos definidos por ANDRADE, conforme segue:

É neste campo que tem lugar as tecnologias eletrônicas de controle, bancos de dados, pulseiras e toda gama de objetos para o monitoramento de presos. É neste campo que se teoriza acerca do «Direito penal do inimigo» (Güinter Jackobs), a antecipação da tutela penal, o fortalecimento dos crimes de perigo. É neste campo que se redefinem as funções da prisão, da ressocialização para a neutralização e o isolamento. É neste campo que se fala da passagem do "controle disciplinar" para o "controle atuarial".

A natureza burocrática e a ausência de debate em torno desta legislação é em si revelador de seu potencial discricionário. Os conhecimentos biológicos tem sido ao longo da história intensamente utilizados para oferecer "certezas" à área penal, como é conhecido. A natureza "exata", socialmente atribuída ao campo de saber biológico é mobilizada para contribuir com a "normalização" dos controles sociais-penais, além de seu status de saber científico, pouco importando as observações de Karl Popper para quem o valor da ciência residia justamente na possibilidade de sue falseamento e não da extração de certezas (POPPER, 1978).

Eis o campo de discussão que nos apresenta, de uma lado, o paradigma dos direitos fundamentais dos condenados e do outro, os efeitos do referido artigo 9-A da Lei de Execuções Penais, que lhes destituí do direito ao silêncio. A dialética proposta ao nosso tempo entre liberdade e segurança parece pairar sobre a modernidade tardia, segundo BAUMAN (BAUMAN, 2001). Dos cenários da ficção científica, o banco de dados de perfil genético ergue-se com a promessa de superação do panoptismo, numa arena em que o conflito revela-se instaurado à luz do direito fundamental de 
não-incriminação. Neste sentido, sustentaremos, também a partir de BAUMAN, que a dinâmica processual penal atual do Brasil atua em uma espécie de pós-panóptico, em suas múltiplas nuances.

\section{PERFIL GENÉTICO NA EXECUÇÃO PENAL: SELETIVI- DADE PROGRAMADA EM BUSCA DE SUSPEITOS}

Em decorrência da Lei 12654/2012, a identificação de perfil genético deverá obrigatoriamente ser realizada em condenados por crime praticado, dolosamente, com violência de natureza grave contra pessoa, ou por qualquer dos crimes previstos no artigo $1^{\text {o }}$ da Lei 8072/90, através da extração de DNA - ácido desoxirribonucleico, e será armazenada em banco de dados sigiloso (artigo 9-A da LEP).

Uma apreciação até certo ponto estética da letra "A" ao corpo do artigo de uma lei tradicionalmente desrespeitada pelo poder público é sugestivo. Enquanto outros tantos artigos adormecem na inércia estatal, acrescenta-se um novo de conteúdo obviamente repressivo. Nada de novo, levando-se em conta que a tradição da codificação brasileira começou com o Código Criminal de 1831, muito antes do ordenamento civil. Como assevera MAUSS (MAUSS, 1974), "os fenômenos jurídicos, da mesma forma que os da língua, são os mesmos que representam o que é de mais característico de uma sociedade". Neste caso, o primado da ordem, sempre lembrado em nossa bandeira, é constantemente recuperado pela abundante produção de leis na lavoura penal brasileira. A inflação de normas penais enfatiza justamente a impotência do exercício de controle social pelo Direito.

0 banco de dados foi regulamentado no Decreto $\mathrm{n}$ 응 7950/2013, que instituiu o Banco Nacional de Perfis Genéticos e a Rede Integrada de Bancos de Perfis Genéticos (RIBPG), transferindo as competências de gestão e controle da rede a um comitê gestor, composto por cinco representantes do Ministério da Justiça, um representante da Secretaria de Direitos Humanos 
e cinco representantes dos Estados e ou Distrito Federal. A normativa delegou ao Ministério da Justiça a responsabilidade sobre a adoção das providências necessárias à preservação do sigilo da identificação e dos dados de perfil genético.

O decreto dispõe ainda que o perfil genético do identificado criminalmente será excluído do banco de dados no término do prazo estabelecido em lei para prescrição do delito, ou em data anterior definida em decisão judicial. 0 banco deve armazenar os dados, permitindo seu cruzamento e integração à esfera estadual, o que facilitaria o trabalho investigativo da polícia uma vez que se tornaria possível a comparação com condenados de outros estados. 0 material biológico será extraído mediante a coleta de células da mucosa oral, sendo vedada a extração de sangue (art. $2^{\circ}$, $\S \S 1^{\circ}$ e $2^{\text {o }}$ da Resolução $n^{\circ}$ 3/2014 da RIBPG).

A resolução no 3 da RIBPG definiu que para a coleta compulsória do material biológico será exigida a sentença condenatória, ou a guia de recolhimento do condenado ou, ainda, a manifestação expressa do Poder Judiciário determinando a coleta de material biológico para fins de inserção no banco de perfis (art.

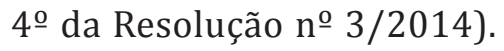

A implementação da lei já se encontra em andamento, sendo possível verificar os dados estatísticos e resultados relativos à novembro de 2014. 0 Comitê Gestor do Banco divulgou relatório ${ }^{1}$, demonstrando que quinze estados da federação já se encontram integrados ao sistema, muito embora $86 \%$ dos dados tenham sido alimentados por seis laboratórios (dos estados do Rio Grande do Sul, Rio de Janeiro, São Paulo, Paraná, Minas Gerais e da Polícia Federal).

0 referido relatório mostra que em novembro de 2014 os dados genéticos de cinquenta e três condenados foram armazenados, e também os dados de vinte e seis investigados. Desde que haja pedido do delegado ou do MP e despacho fundamentado, o

http://www.justica.gov.br/noticias/relatorio_ribpg_nov_2014.pdf/view, acesso em junho/2015. 
sujeito que está sendo investigado será utilizado o seu DNA para desvendar aquele crime específico, e depois ele pode pedir a exclusão do DNA dele do banco). Em contraponto, foram coletados dados de 1524 vestígios, o que possivelmente são considerados investigações penais em andamento ou ainda corpos não identificados ou material biológico para a localização de pessoas desaparecidas, haja vista a ausência de conceituação do termo vestígios pelo relatório.

0 relatório afirma que setenta e uma investigações foram auxiliadas pelo banco de dados, sem que seja possível ao intérprete do relatório verificar de que forma isso ocorreu, exceto pela menção específica da identificação de um corpo, pela Polícia Civil do Rio de Janeiro, de uma vítima de homicídio. À tutela burocrática dos inquéritos e processos se acrescenta novos dispositivos: o banco de dados e os relatórios que se expressam por enigmas hermenêuticos.

Foi possível constatar que os laboratórios participantes da Rede Integrada de Bancos de Perfis Genéticos (conforme dados divulgados pelo Conselho da Justiça Federal) utilizam-se de uma tecnologia semelhante a um software, que responde pelo nome de Combined DNA Index System (Codis). O programa Codis foi importado do FBI em 2010, por intermédio de um convênio firmado com a Polícia Federal.

O DNA é um composto orgânico que coordena a produção de proteínas no corpo. Cada indivíduo possui uma combinação única, o que teoricamente permitiria identificar uma pessoa determinada através de tal dado. 0 que escapa a uma leitura superficial do tema é que, em se tratando de material genético colhido em cena de crime frequentemente verificam-se misturas de dados, podendo interferir no resultado da análise.

Exemplificativamente, caso seja encontrado material biológico no corpo de uma vítima, o material encontrado será necessariamente uma mistura entre o DNA da vítima e o DNA do suposto 
ofensor. Essa circunstância, conforme a literatura especializada, poderá ocasionar falhas na amostra, dificultando a identificação correta do DNA estranho.

Embora a defendida "infalibilidade" dos computadores e softwares utilizados, o método de análise não escapa às injunções da subjetividade humana, mais especificamente de um perito criminal, que adota o método de análise que entenda adequado ao caso. Assim, embora um computador matemático possa indicar a probabilidade de identificação do DNA de um culpado, a interpretação humana sobre os dados indicados pelo software pode falhar (PERLIN, 2011).

Além disso, cumpre sempre lembrar que desde sua emergência, o campo de conhecimento das chamadas Ciências Humanas (ou ainda Ciências Sociais Aplicadas como costumam referir-se ao campo das Ciências Jurídicas e Sociais) é assombrado pelo fantasma de um método infalível capaz de banir a incerteza e fornecer exatidão às suas conclusões, dessocializando a experiência social, este processo implica em construir um estatuto de conhecimento ancorado no conceito de natureza (biológica, neste caso), mas que de certa forma já estava também presente no paradigma do jusnaturalismo moderno com seus conceitos de Direitos Naturais e Estado de natureza. Em resumo, são nos quadros da crise de paradigmas e seu déficit teórico que opera-se o eterno retorno ao paraíso lombrosiano onde muitos teóricos e principalmente operadores do Direito esperam encontrar o conforto da teoria sem possibilidade de falsificação, o que é a própria negação da Ciência (POPPER, op cit.)

Especificamente no que tange ao sistema CODIS, importado do FBI, verificou-se que o mesmo é programado para identificar certos dados e excluir outros, selecionando apenas parte das informações para determinar uma resposta probabilística. Desse modo, quando o dado for lançado no banco de perfis para a busca de uma combinação, é possível que o sistema limite o número de 
suspeitos, com chance de que exclua aquele que seja realmente culpado, propiciando a identificação de algum inocente incorretamente (PERLIN, 2011).

Nos EUA, onde essa técnica já é utilizada há mais tempo, os pesquisadores da área já apontam uma série de inconsistências da identificação do DNA quando a amostra contém mistura de materiais biológicos (PERLIN, 2007, p. 23-30), o que faz com que os tribunais estadunidenses, durante os julgamentos, permitam a revisão da metodologia de análise por peritos diversos, como ocorreu no caso Pennsylvania x Kevin Foley.

No caso referido, o policial Kevin Foley foi acusado pelo homicídio do dentista John Yelenic, pois teria sido encontrado nas unhas da vítima vestígios de DNA misturados (os da própria vítima e de terceiro). As análises comparativas apontaram uma probabilidade de 1 chance em 13 mil de ser o material genético estranho encontrado do acusado, o que, segundo a defesa, não seria confiável já que a população da Pennsylvania contava com mais de 13 milhões de habitantes.

O banco de dados de perfil genético opera através do cálculo de probabilidades de combinações, então, quanto mais dados armazenados estiverem disponíveis no banco de perfis maiores tornam-se as possibilidades de combinação dos dados (DNA encontrado na cena do crime x DNA armazenado nos bancos), elevando-se o grau de segurança da resposta matemática.

Os dados divulgados pela Rede Integrada do Ministério da Justiça mostram um panorama completamente desfavorável à segurança dos resultados, tendo em vista que foram coletados dados de apenas 53 condenados, sendo a totalidade desses provenientes dos estados do Ceará e de Minas Gerais (cuja população soma quase 30 milhões de habitantes).

Assim, a resposta probabilística de eventuais combinações pelo banco de perfis pode constatar mais facilmente a identificação dos perfis daqueles que se encontram no banco, eis que necessárias 
menos combinações. Dito de outra forma, só será possível afirmar a combinação em relação a quem está no banco, o que favorece que sejam condenados apenas estes selecionados, deixando de lado aqueles que por força das injunções sociais presentes na seletividade jurídico-criminal dificilmente entrarão na execução penal para ser forçado a entregar material genético. Trata-se da óbvia reificação da perversidade social que implementa uma espécie de seletividade dentro dos fluxos da seletividade mais tradicional. Agora a legitimidade atribuída a modernidade científica presta-se a execução das mesmas notas perversas de um modelo punitivo sempre excludente de determinados grupos sociais.

Os números do relatório demonstram que mais de $65 \%$ do material genético coletado pertence a condenados, favorecendo uma seletividade programada pela máquina (o software é pré-programado para identificar o DNA conforme aproximação), sendo evidente que se as amostras se basearem em comparações de poucos DNAs, maiores são as chances de o resultado direcionar um culpado dentre aqueles que possuem material armazenado no sistema. Em outras palavras, um software que opera em busca de "suspeitos" que, provavelmente serão os mesmos "clientes do sistema de justiça criminal brasileiro.

Este levantamento de dados permite afirmar a superação do modelo de engajamento demandado pelo panóptico, potencializando a velocidade do poder disciplinar a partir do distanciamento entre o vigiado e o vigia, que se reconfiguram enquanto número (código ou dado) e máquina (sistema de análise), respectivamente. Bauman explica que

o que importa, nas relações de poder pós-panópticas é que as pessoas que operam as alavancas do poder de que depende o destino dos parceiros menos voláteis na relação podem fugir do alcance a qualquer momento - para a pura inacessibilidade. (BAUMAN, 1999, p. 16-18). 
Isto porque no panóptico a rotina disciplinar entre os vigias e os internos demandava necessariamente algum grau engajamento e de aprisionamento dos próprios administradores com os vigiados, pois submetidos ao mesmo regime de tempo e lugar, pois "o que importava no Panóptico era que os encarregados "estivessem lá", próximos, na torre de controle". (BAUMAN, 2001). 0 modelo torna-se desvantajoso não apenas pela necessidade de construção e manutenção de uma estrutura para o seu desenvolvimento, mas também sob a ótica de comprometimento com a preservação e o bem estar dos internos, ou seja, havia um certo grau de relacionamento entre vigia e vigiados, o que se esvai na relação de poder pós-panóptica.

Este contexto ilustra a conjuntura criticada por Vera Andrade ao denominar de paradigma bélico o modelo de segurança pública essencialmente punitivo desenvolvido no país, de norte defensivista, que prioriza o combate à "criminalidade" em detrimento dos direitos humanos do cidadão.

O paradigma punitivo da segurança "da" ordem (e "contra" a criminalidade) em detrimento da segurança dos direitos culminou, dessa forma, por polarizar a sociedade entre potenciais infratores e potenciais vítimas, replicando nesta polarização a desigualdade, a luta de classes e as assimetrias de gênero, raça e outras. Esse modelo, que pode com razão ser denominado por paradigma bélico, tem a sustentá-lo uma estrutura social, uma engenharia e uma cultura punitivas. (ANDRADE, 2013, p. 340)

Todos esses elementos demonstram um sintoma de que a era do pós-panóptico chegou para ficar. Com o banco de dados de perfil genético, aliado ao monitoramento eletrônico, às audiências por videoconferência, o processo eletrônico, dentre outras práticas de controle, não resta dúvida que as estratégias de biopoder não cessam sua capacidade de se auto-reproduzirem. 


\section{CONSIDERAÇÕES FINAIS: PARA UMA CRÍTICA INTERDIS- CIPLINAR AO BANCO DE DADOS}

Os parágrafos anteriores sugerem um amplo conjunto de reflexões de caráter interdisciplinar. Os cenários de um "Admirável Mundo Novo" descrito por Aldous Huxley em seu celebrado romance se descortinam para aqueles que partilham o delírio onírico da neutralidade científica ou da dicotomia entre Direito e Moral. Como nos lembra MAUSS (MAUSS, 1974) e, antes dele Durkheim: "Os fenômenos jurídicos são fenômenos morais organizados. A consciência moral introduz a consciência na concepção jurídica". Eis os termos de uma reflexão crítica sobre o banco de dados genético.

Uma "seletividade programada" já está em curso no sistema jurídico-criminal brasileiro. Ela não é muito diferente das práticas repressivas que estruturam as relações sociais no Brasil. Nos primórdios da construção do direito moderno no Brasil, o Estado já reivindicava para si a prerrogativa de executar os castigos físicos aos escravos. Ao longo da história e sem arranhar a ordem social brasileira, os ordenamentos jurídicos receberam adereços de racionalidade liberal miscigenando-se à ordem patrimonial. Assim, implantamos a igualdade iluminista sem eliminar a escravidão. Por que o banco de dados genético nos ofereceria uma ordem de valores diferente? ${ }^{2}$

Evidentemente o Direito Processual Penal não está imune às evoluções científicas em torno dos métodos de obtenção da prova criminal, sendo deveras sedutor às agências de punitividade o

2 Ao contrário do que se afirma, o Brasil está muito longe de ser o país da impunidade. Quarta maior população prisional do mundo, o ritmo de prisonalização em nosso país supera os primeiros colocados. Neste conjunto grande parte da população prisonal é constituída de jovens pardos e pretos oriundos das periferias metropolitanas, detidos por crimes de baixo potencial ofensivo e/ou presos com pequenas quantidades de drogas sem uso de armas. Além disso, mais de um terço dessa população selecionada pelo aparato jurídico-criminal encontra-se em prisão provisória. Dados www. justica.gov.br/seus-direitos/politica-penal/transparencia-institucional/ estatisticas-prisional. 
recurso ao perfil genético, que ressuscita os antigos postulados criminológicos positivistas acerca do homem delinquente (Ferri, Garófalo e Lombroso), o que foi superado pelo paradigma da reação social (ANDRADE, 1995).

Assim, a lei traz dois pesos e duas medidas, sendo ao investigado está assegurado que a colheita de material biológico somente se dará com deferimento judicial, em caso de necessidade demonstrada. Enquanto isso, o condenado terá seu material genético colhido compulsoriamente, pois assim a lei determina.

Esse reingresso do sistema jurídico-criminal brasileiro na modernidade a partir da criação do banco de dados genético se faz a partir de um modelo aberto a toda a sorte de escolhas discricionárias. Do banco de dados dos condenados passando pela referida resposta probabilística estamos muito próximos daquilo que Foucault, em 1976, já denominara de biopolítica, uma nova forma de gestão da diversidade social: "A biopolítica lida com a população e a população como problema político, como um problema a um só tempo científico e político, como problema biológico e como problema de poder..." (FOUCAULT, 1999) Não se trata, obviamente de abrir mão das instituições disciplinares clássicas, mas de introduzir aperfeiçoamentos regulamentadores a um quadro que se apresenta em constante mutação.

0 banco de dados genéticos mostrou-se como um mecanismo de vigilância desengajada em relação ao modelo anterior, no qual a disciplina dependia de uma relação entre o vigia e o interno, pois conectados no espaço e no tempo, o que se esvaiu e se transmudou em inacessibilidade, de modo que o poder pode se mover com a velocidade do sinal eletrônico - e assim o tempo requerido para o movimento de seus ingredientes essenciais se reduziu à instantaneidade. (BAUMAN, 2001).

A integração da sociedade brasileira aos quadros do "capitalismo flexível” implicou uma redefinição profunda da própria lógica da sociedade capitalista que passa operar numa dinâmica 
de exclusão contínua na qual "o outro desviante está em toda a parte" e a insegurança ontológica se dissemina (YOUNG, 2002). Os desdobramentos desta integração expressou-se, grosso modo, num amplo cenário de desregulação das relações sociais que precarizou e vitimizou notadamente as camadas subalternas da sociedade, diante do desmantelamento das funções de promoção social do Estado.

A resposta, evidentemente reativa a este quadro traduziu-se no aprofundamento das estratégias panópticas tradicionais de exclusão social e aprofundamento da distopia urbana das quais o aprisionamento em massa é sua expressão mais tradicional e a militarização do cotidiano de comunidades específicas, mediante "ocupação", sua panacéia midiática mais atualizada (GRAHAM, 2015). Mas também este espaço social sofrerá a sobreposição funcional de práticas regulatórias pós-panópticas das quais o banco de dados genético extrai sua inspiração. Assim como no passado quando as primeiras campanhas de vacinação coincidiam com a reforma urbana do barão Houssemann, novamente a biologia é convocada a ofertar seus status purificador das "massas impuras" numa sociedade que parece estar travando outra variante do "choque de civilizações", apregoado por Samuel Huntington.

Sempre expressando sua leitura específica da modernidade ocidental, o Brasil com suas tradições patrimoniais e desigualdades estruturantes da ordem social, integra-se às novas práticas penais. Seletividade e probabilidade andam de mãos dadas nestes novos procedimentos da mesma forma que o DNA e a execução pretendem ser o novo veículo da tão almejada "verdade real". Depois do suplício, a prisão, depois desta, o banco de dados e sua administração. No amplo espaço aberto pela solução probabilística os espirais irão fazer aquilo que Kant de Lima definiu como a persistência da tradição inquisitorial brasileira a qual nos referimos anteriormente (KANT DE LIMA 2006). 


\section{REFERÊNCIAS}

ANDRADE, Vera Regina Pereira de. A mudança do paradigma repressivo em segurança pública: reflexões criminológicas críticas em torno da proposta da $1^{0}$ conferência nacional brasileira de segurança pública. Disponível em: http://www.scielo.br/pdf/seq/n67/13.pdf.

. Movimentos contemporâneos do controle do crime. http://www. geocities.ws/criminologia.critica/artigos/movimentos.pdf

. Do paradigma etiológico ao paradigma da reação social: mudança e permanência de paradigmas criminológicos na ciência e no senso comum. Revista Seqüência (Florianópolis), Florianópolis, v. 30, p. 24-36, 1995. Disponível em: http://www.metajus.com.br/textos_nacionais/ Criminologia-paradigmas.pdf

BAUMAN, Zigmunt. Modernidade Líquida. Rio de Janeiro: Jorge Zahar Editores, 2001.

BetTiOL, Giuseppe. Instituiciones de Derecho Penal y Processal. Trad. Faustino Gutierrez-Alviz y Conradi. Barcelona: Bosch, 1976.

BOURDIEU, P. O poder simbólico. 4. ed. Rio de Janeiro: Bertrand Brasil, 2001.

BUENO DE CARVALHO, Amilton. Lei, Para que(m)? In: WUNDERLICH, Alexandre. (Coord.) Escritos de Direito e Processo Penal em Homenagem ao Professor Paulo Claudio Tovo. Rio de Janeiro: Lumen Juris, 2001.

CARNELUTTI, Francesco. Verità, Dubbio e Certezza, Revista di Diritto Processuale, v. XX (II serie), 1965.

COUTINHO, Jacinto Nelson de Miranda. Glosas ao Verdade, Dúvida e Certeza de Francesco Carnelutti, para os operadores do Direito. In: Anuário Ibero-Americano de Direitos Humanos, 2001.

FONSECA, Anderson Lobo. http://www.diplomatique.org.br/artigo. php?id=1859.

FOUCAULT, Michel. Em Defesa da Sociedade. São Paulo: Martins Fontes, 1999.

GRAHAM, Stephen. 0 Bumerangue de Foucault: o novo urbanismo militar. São Paulo: Boitempo Editorial, 2015.

LIMA, Kant de. Antropologias do Direito. Rio de Janeiro: Lumen Juris, 2006. 
LOPES JÚNIOR, Aury. Direito Processual e sua conformidade constitucional. 9a ed. Rio de Janeiro: Saraiva, 2012.

MAUSS, Michel. Sociologia e Antropologia, v. I. São Paulo: E.P.U./ EDUSP, 1974.

PERLIN, Mark, W. Mass casualty identification through DNA analysis:

overview, problems and pitfalls. Forensic Investigation and Management of MassDisasters. M. I. Okoye and C. H. Wecht. Tucson, AZ, Lawyers \& Judges Publishing Co, pp. 23-30, 2007.

PERLIN, M.W. DNA Intelligence and Forensic Failure: What you don't know can kill you. Cybergenetics Newsletter - Winter 2011.

POLANYI, Karl. A grande transformação: as origens de nossa época. Trad. Fanny Wrabel. Rio de Janeiro: Compus, 2000.

POPPER, Karl. Lógica das Ciências Sociais. Rio de Janeiro: Tempo Brasileiro, 1978

ROXIN, Claus. La protección de pa persona en el Derecho Procesal Penal alemán, In:: La evolución de la Política Criminal, el Derecho Penal y el Proceso Penal, Valencia: Tirant lo Blanch.

SANTOS, Boaventura de Sousa. Democratizar a Democracia: Os Caminhos da Democracia Participativa. Rio de Janeiro: Record. 2002

SORJ, Bernard. A Nova Sociedade Brasileira. Rio de Janeiro: Jorge Zahar Editores, 2000.

WEBER, Max. Economia e Sociedade. Brasília: Editora UNB, 1972.

YOUNG, Jock. A sociedade excludente. Exclusão social, criminalidade e diferença na modernidade recente. Rio de Janeiro: Revan, 2002. 